\title{
A Review of the Anthropogenic Effects of Climate Change on the Physical and Social Environment
}

\author{
Jackob Haywood Ondiko, Amon M. Karanja, Opole Ombogo \\ Department of Geography, Egerton University, Nakuru, Kenya \\ Email: ondikojackob2018@gmail.com, amon.karanja@egerton.ac.ke, opoleiro@gmail.com
}

How to cite this paper: Ondiko, J.H., Karanja, A.M. and Ombogo, O. (2022) A Review of the Anthropogenic Effects of Climate Change on the Physical and Social Environment. Open Access Library Journal, 9: e7751.

https://doi.org/10.4236/oalib.1107751

Received: July 12, 2021

Accepted: February 12, 2022

Published: February 15, 2022

Copyright $\odot 2022$ by author(s) and Open Access Library Inc.

This work is licensed under the Creative Commons Attribution International License (CC BY 4.0).

http://creativecommons.org/licenses/by/4.0/

\section{(c) (i) Open Access}

\begin{abstract}
Literature review of effects of climate change on the physical and social environment was conducted where impacts at global, regional, national and local scales were considered. The literature review was based on past studies where library and online sources covering the past two decades were analyzed. Noted relevant findings were then critically analyzed and used to develop the article where the parameters of climate change and effects were identified and discussed. The review established that the environment is negatively affected by climate change; a natural climatic phenomenon arising from variation of global temperatures caused by green-house effect and global warming. Notably, climate change threatens productivity and sustainability of biotic and abiotic environments. Climate change is primarily linked to increased anthropogenic activities that enable Green House Gas (GHG) emission into the atmosphere. Climate change leads to extreme climatic events such as heat stress, drought stress, water stress and hazardous atmospheric circulation and flooding causing significant impacts on the environment. Climate change leads to reduction in economic productivity of agronomic systems, increasing natural resources vulnerability levels and degradation of the ecosystem reducing its productivity and biotic sustainability. The paper identified the knowledge gaps in the quantification of the impact of anthropogenic driven climate change on the environment and mitigation strategies upon which climate change experts can potentially prioritize future research for relevant policy development.
\end{abstract}

\section{Subject Areas}

Aerography

\section{Keywords}

Climate Change, Global Warming, Green-House Effect 


\section{Introduction}

Climate change is the alteration in statistical and climatic properties such as precipitation, temperature, wind patterns and humidity over an elongated period of time, arising from natural events and anthropogenic activities [1]. Even though the atmosphere can also be heated through natural activities such as solar radiation and volcanicity [2], this study was restricted to the anthropogenic activities that influence climate change and the impact of the events. Anthropogenic activities such as industrialization, motorized transportation and mechanized farming are the principal sources of GHGs which cause climate change leading to loss of biodiversity [3] [4]. The rapidly increasing global population has also caused a large strain on natural, economic and human resources where increased demand for goods and services has equally increased. The production of these goods and provision of the services result in increased atmospheric pollution from GHGs. Release of GHGs such as carbon dioxide $\left(\mathrm{CO}_{2}\right)$, methane $\left(\mathrm{CH}_{4}\right)$, nitrous oxide $\left(\mathrm{N}_{2} \mathrm{O}\right)$ and water vapour $\left(\mathrm{H}_{2} \mathrm{O}\right)$ have led to the accumulation of gases in the atmosphere [5] [6]. The atmospheric concentration of the GHGs form a thick blanket which blocks the dangerous solar radiation from being reflected back to the atmosphere causing increases in global temperatures over time [5] [6].

According to a study conducted on health, environment and climate change, approximately one quarter $(13,000,000)$ human deaths are associated with climate change environmental risks that can be avoided [7]. The study also found that air pollution alone accounts for 7,000,000 deaths annually and approximately $90 \%$ of the global population inhaling polluted air. Further, the study established that unsafe water and unhealthy environmental conditions created by climate change and anthropogenic activities are experienced by more than $50 \%$ of the global population, with approximately 800,000 deaths per year. Even though these statistics indicate the impact of climate change on the physical and social environment, the study pointed out that prediction of climate change impacts on the quality of a given environment is still a challenge. The high value of statistics of climate change-related deaths indicates relative economic loss both for the affected governments and families.

Effects of climate change such as global warming leads to depletion of the ozone layer, destruction of atmospheric genetic diversity and consequent increase in warming and loss of atmospheric productivity [8]. In addition, loss of biodiversity increased release of GHGs, particularly $\mathrm{CO}_{2}$ from deforestation of carbon sinks and natural decay or anthropogenic bush burning [9]. The study also indicated that exploitation of peat-lands is likely to increase climate change due to accumulation of $\mathrm{CO}_{2}$ in the atmosphere. Currently, effects of atmospheric $\mathrm{CO}_{2}$ are experienced through increased global warming occasioned by green-house effect. Green-house effect also leads to increased destruction of ecosystems through warming and increase in acid rainfall. The acid rainfall notably leads to increased destruction of crops and buildings. Further increase in quantity of $\mathrm{CO}_{2}$ in the atmosphere will also potentially increase aerobic and dermic diseases. 
The United States of America (USA) produces a fifth of the global GHG emissions [5] [10]. The net effects of the cyclical global warming process caused by anthropogenic activities have led to increased aridity. Further, land degradation is also recorded thereby limiting productivity of farmlands and land-based biotic resources. In addition, these anthropogenic undertakings increase the occurrence of climatic phenomena such as heat and water stress that can potentially decimate biotic systems on earth if not adequately checked.

Temperature-water nexus is critical to vegetative land cover, existence of animals and agricultural production. The variations in both temperature and rainfall affect rain-fed agronomic systems which are predominant in South Africa and numerous other developing nations [5]. In addition, the study noted that the optimal functionality of the various ecosystems (terrestrial, aquatic and atmospheric) are equally significantly affected by climate change hence declining ecosystems productivity and declining biotic systems sustainability. It is notable that increased ecosystem destruction and land degradation has increased aridity in South Africa, where deficient atmospheric moisture conditions and warming are recorded during the frequent drought periods.

Climate change has significantly impacted climatic conditions in East Africa with increased rainfall recorded in some parts of the region [11]. In contrast, decline in rainfall is also recorded in some parts of the region [12] [13]. Tanzania and Kenya are significantly affected by climate change due to location, demographic structures and low climate change mitigation and adaptation capabilities [14] [15]. In addition, the studies reported that drought stress, rainfall and temperature variability are recorded in Kenya. The observed variations in rainfall occurrence and patterns in Kenya is a major threat to rain-fed crop production. Considering that ASALs cover the largest surface area in the country and low crop yields from the ASALs are regularly recorded; the threat of food insecurity appears real for the inhabitants of the drylands in Kenya. The impending threat of food insecurity due to climate change therefore is a major cause for worry for the government of Kenya as well as the smallholder crop farmers in the drylands.

Even though climate change is majorly identified through global warming, there are a number of parameters such as temperature, rainfall, drought stress, wind patterns, humidity and GHGs, whose variability are used to determine the variations in climatic changes. These parameters consequently aid in the identification of the relative effects of climate change. This study therefore has identified and discussed the climate change parameters and their relative effects on the physical and social environment.

\section{Discussion}

Climate change is the variation in global temperatures arising from global warming and green-house effect caused by natural and anthropogenic factors [1]. Even though attempts have been made to manage the impacts of climate change, 
there is a large spatio-temporal extent of the impact, whose mitigation demands long-term and significant transformation of the environmental resources consumption patterns [16]. The physical environment provides a number of resources such as terrestrial, aquatic and atmospheric ecosystems [17] [18]. These resources sustain life on earth and are exploited in a number of ways for products and services. The products are consumed as food, used in industrial development, urbanization and agronomic production. However, climate change poses a severe threat to the sustenance of life on earth by negatively impacting on these natural resources. Facing the imminent threat from climate change therefore, the sustainable use of environmental resources will guarantee their availability for the future generations and for genetic posterity.

Deforestation globally contributes approximately $20 \%$ of GHGs [5] [10] while global $\mathrm{CO}_{2}$ emissions increased by $1.6 \%$ and $2.7 \%$ in 2017 and 2018 respectively [19]. USA produced GHGs as follows: $\mathrm{CO}_{2}, \mathrm{CH}_{4}, \mathrm{~N}_{2} \mathrm{O}$ and Fluorinated Gases at $82 \%, 10 \%, 6 \%$ and $3 \%$ respectively [20]. In addition, the studies approximated $20 \%$ of the global GHG emissions as originating from USA. The statistics of GHG emission in USA indicates a high quantity of atmospheric GHGs whose concentration is a major threat to biotic systems on earth. The flora and fauna on terrestrial surfaces and aquatic systems optimally grow and thrive under specific climatic and ecological environments. These environments will be potentially disturbed by GHG-driven global warming. In consequence, if not appropriately checked, the terrestrial and aquatic life forms will be terminated or displaced thereby limiting the chances of survival.

Even though reduction of atmospheric $\mathrm{CO}_{2}$ to 350 parts per million is advised, in 2010, $\mathrm{CO}_{2}$ atmospheric concentration was as high as 392 parts per million [6]. Climate change leads to increase in concentration of $\mathrm{CO}_{2}$ in the atmosphere leading to acid rains and acidification of oceans [10]. The increased ocean water acidification also alters the growth conditions of aquatic species and the increase in nitrification of surface water also leads to decline in water quality. $\mathrm{CO}_{2}$ concentration in the atmosphere is an important climate change driver [20]. However, $\mathrm{CO}_{2}$ concentration influences agronomic production, where deficit in $\mathrm{CO}_{2}$ concentration in soil limits crop production [21].

China emitted $27.6 \%$ of the world's $\mathrm{CO}_{2}$ from combustion of fossil fuels in 2013 [22]. The high emission of $\mathrm{CO}_{2}$ by China caused air pollution and acid rains and is considered the world's largest emitter of the GHGs. In addition, the study noted that in the past three decades, the average annual temperature in China rose by 1.0 degrees Celsius $\left({ }^{\circ} \mathrm{C}\right)$. The increase in $\mathrm{GHG}$ emission and the consequent increase in temperatures in China have potentially led to the notable evolution of wetlands in the country. In addition, the heat wave events and variability in rainfall experienced in China are associated with climate change.

While evaluating global temperature variations using Global Climate Model, projections of $1.4^{\circ} \mathrm{C}$ to $5.8^{\circ} \mathrm{C}$ temperature rise per year in the $21^{\text {st }}$ Century was realized [23]. In concurrence with these projections, climate change arising from 
anthropogenic forcing which led to rise in atmospheric temperatures by $1.9^{\circ} \mathrm{C}$ from 1901 to 2014 was noted [2]. Variables of climate change such as temperatures influence agronomic production, where high and low temperatures limit crop production [21]. A rise in temperature also results in increase in transpiration water demand and use [24] [25]. Increased transpiration leads to water stress which results in soil moisture deficit. Deficit in soil moisture limits the vegetative growth and distribution and lowers production and productivity of plants where loss in crop yields may also be registered. In addition, the increased atmospheric temperatures result in increase in soil temperatures that may rise above the optimal plant growth conditions thereby limiting plant phenological processes.

An increase of $0.34^{\circ} \mathrm{C}$ and $0.1^{\circ} \mathrm{C}$ to $0.2^{\circ} \mathrm{C}$ in lake water temperatures every decade from 1985 to 2009 globally with projections pointing at $4.0^{\circ} \mathrm{C}$ by the end of the $21^{\text {st }}$ Century was established [2]. The study also revealed that climate change leads to increase in salinization thereby reducing aquatic productivity. Climate change also leads to coral bleaching from warmer seas, stagnation of coral growth and reduces natural coastal protectors such as coral [26]. Increase in ocean water temperatures therefore not only poses a major threat to biotic aquatic systems but also threaten the abiotic conditions such as coral islands that support aquatic life forms. Increased physical and chemical weathering of these features, lead to destruction of aquatic species habitats resulting in migration. In addition, the increase in temperatures of global water bodies can potentially alter the aquatic ecosystem functions and lead to migration or loss of aquatic animals

The impact of climate change was exhibited in 1994, 2000, 2002 and 2003 which were marked as the hottest years in France in the last three decades [5]. The study approximated a significant decline of 5 metres in the snow cover in Avoriaz Ski Station in France by 2013 from the initial $13 \mathrm{~m}$ in 1970. Consequently, a notable increase in amount of water in water bodies in France was reported. The significant reduction in snow cover manifested the significant impact of climate change, thereby limiting human and economic activities. However, these reductions in snow cover led to rise in water level in lakes and seas in Europe.

Global sea level rises at $3 \mathrm{~mm}$ annually due to climate change [27]. Projections of a rise in sea level globally indicate 0.26 to $0.77 \mathrm{~m}$ rise by 2100 for the $1.5^{\circ} \mathrm{C}$ global warming [28]. In addition, the study predicted a $0.2^{\circ} \mathrm{C}$ rise per decade in surface temperatures. Further projections of $1.5^{\circ} \mathrm{C}$ rise in temperatures were registered to be experienced in Caribbean region by 2030. Climate change also leads to oceanic thermal expansion thereby increasing volume of oceans and rising sea levels and glacial melts [26]. Further, a projected 35 centimetre increase in sea level in the Mediterranean basin where projections of $2.2^{\circ} \mathrm{C}$ to $5.0^{\circ} \mathrm{C}$ increase in temperature were also indicated [24]. The projections of increase in global temperatures and the subsequent rise in sea level will potentially increase the cases of submergence of coastal islands and salinity of coastal farm- 
lands. These effects on coastal lands will further displace coastal communities and coastal urban dwellers besides reducing the availability of consumable fresh water from coastal rivers.

Climate change leads to inundation due to rise in sea level, damage by storms, evolution of wetlands and of coastal lands [29]. Further, the study pointed out that increased salinization of coastal waters due to sea saltwater intrusion affects approximately 600,000,000 people globally. In addition, the study reported that $30 \%$ of the arable coastal lands in Bangladesh are threatened by salinization and flooding from tidal rise during the wet periods.

Climate change was noted as leading to increased temperatures of $0.5^{\circ} \mathrm{C}$ per decade in mountain areas in Africa [30]. The positive trend in temperature was linked to the mountain top glacial melt where up-to $80 \%$ of the area under glaciers has receded in the past three decades. In concurrence, increase in atmospheric warming was also indicated to be influencing terrestrial ice coverage [24] [31]. The studies also established increase in ice melts from icebergs arising from increased temperatures due to climate change. Notably, the increased glacial and ice melt reduces the terrestrial surface and ocean surface and sub-surface cyrospheric water storage. The reduction in cyrospheric water sources consequently limits the availability of fresh water.

Oxygen levels in surface water are reduced due to saturation level by temperatures, while an increase in nutrient levels enhances respiratory processes in water affecting aquatic species [32]. Further, high aquatic temperatures inhibit dissolution of oxygen in surface water hence limits the amount of water oxygen for aquatic animals [10]. In addition, evaluated oxygen levels in water bodies in areas affected by climate change, indicated that increased water and atmospheric temperatures lead to increase in primary production and nutrient cycling rates in the water bodies thereby lowering dissolved oxygen levels [33]. In effect, the decline in water oxygen leads to death of aquatic organisms and also accelerates eutrophication and water turbidity, pollution and aquatic habitat degradation. Moreover, extreme weather events are projected to change the physical and chemical water quality where concentration of oxygen in surface water will decline.

Climate change leads to decrease in fresh water sources which will negatively impact approximately 1.8 billion people by 2080 [6] [18]. The studies also revealed that climate change reduces amount of water in rivers, lakes and some seas. Climate change also affects the hydrological cycle where limited water leads to alteration of optimal functioning of the ecological systems or destruction of the ecosystems. The resultant loss of biodiversity leads to migration of animals or extinction of plant species. The decrease in fresh water sources may also lead to desiccation of swamps and water. In addition, an increase in dry river beds and salars will be recorded thereby increasing wastelands.

Observable and measurable characteristics of soil such as soil composition and productivity have been used to assess impacts of climate change in North Amer- 
ica, where temperature models have projected increase by $2.0^{\circ} \mathrm{C}$ to $3.0^{\circ} \mathrm{C}$ in the next decade [33]. Climate change leads to increased soil $\mathrm{pH}$ and nitrification from atmospheric sources [2] [21]. Further, the studies noted that climate change leads to increased soil salinity and altered the soil nutrient cycle thereby reducing soil quality and productivity. The consequent decline in soil quality limits plant growth and productivity where stunted growth may be observed.

Climate change alters the growth, spread and activity of soil organisms [34]. In addition, the study realized that the composition of species and communities and their interaction with soil are equally altered consequently disrupting the soil food webs. The disrupted interaction of primary producers and consumers in soil limits soil health and productivity. The limited soil health and productivity consequently leads to reduced terrestrial vegetation cover and crop yields. Furthermore, the limited terrestrial vegetation cover leads to low transpiration rates hence low atmospheric humidity.

Atmospheric humidity is a key indicator of climate change and determines amount of precipitation [22]. The variation in precipitation influences soil nitrogen and $\mathrm{CO}_{2}$ concentrations hence determining crop yields. Rainfall deficit leads to less humid conditions where urban heat islands may experience low humidity [2]. These urban climatic conditions are completely different from the typical climates of the peripheral surrounding regions. In addition, climate change may also increase rate of alteration of relative humidity and cloud cover in the near future due to increasing global temperatures. Variation in humidity or atmospheric water vapour leads to variation in amount and distribution of cloud cover and rainfall. Furthermore, variation in humidity alters atmospheric temperature conditions. The change in amount of rainfall and atmospheric temperatures consequently influence the vegetation growth conditions.

Climate change led to increase in precipitation in USA from $5 \%$ to $10 \%$ in the $20^{\text {th }}$ Century, projecting an increase in the amount of water in water bodies [33]. However, a decline in hydrographs in parts of North America that experienced negative significant climate change and variation in precipitation was observed in the $20^{\text {th }}$ Century [33]. The decline in hydrographs was manifested in reduced water quantity in water bodies which led to increased nutrient and dissolved organic matter concentrations. These concentrations increased the quantity of pathogens and microbes in the water bodies thereby increasing disease cases. A further decline in rainfall in parts of South America between 2006 and 2007 was recorded and linked to the variations to climate change [11]. Significant rainfall variability in North and North-West Brazil from 1901 to 2010 was also established [35]. The negative change in precipitation manifested by deficits in rainfall resulted in deficit in soil moisture in parts of South America. Limited soil moisture therefore affected agricultural production and yield levels besides ecosystem degradation in the region.

Even though some parts of the world experienced negative rainfall anomalies, climate change was identified as leading to $10 \%$ to $20 \%$ increase in rainfall ano- 
malies in the winter season in the United Kingdom [32]. The study noted that the increased precipitation resulted in increased inundation, chemical and soil deposition in water bodies thereby lowering water quality. The variations in patterns and amounts of rainfall in different regions are associated with climate change.

Even though water is a vital factor in the germination of crops with sorghum water imbibition process requiring seed water content to be $35 \%$ to $45 \%$ of the dry mass of the seed, climate change instigated soil moisture stress is a big challenge to crop production in ASALs [36]. Further, high water retention capacity of loam soils accelerates nitrogen dissolution and absorption by crop roots [37], however, the study reported that variability of rainfall hence soil moisture can potentially alter the structure of soils thereby limiting crop production and vegetative cover. Climate change also leads to water stress which affects crop flowering and grain filling phases leading to decline in crop production and yields [38]. The threat posed by climate change through variability of rainfall therefore, is a major cause for worry for the smallholder crop farmers, majority of who depend on rain-fed agriculture for food crop production. With the near annual food insecurity experienced in most of the developing countries, irregular trends and decreasing amounts of rainfall contend a bleak future for many inhabitants of ASALs in these countries.

Projections of increase in temperature of $2.0^{\circ} \mathrm{C}$ to $6.0^{\circ} \mathrm{C}$ during the next one century have been recorded in Africa [39]. The study also identified projected increase in frequency of droughts arising from variable rainfall patterns that are linked to climate change in the continent. A reported relative increase in climate hazards such as droughts, were also noted to increase vulnerability levels in Africa [40]. The high projections of increase in temperatures and droughts in Africa are notably a cause for worry for the continent which is exposed and has low climate change adaptability. In addition, Africa is largely dependent on rainfed agriculture where majority of the rural population is employed.

There is increase in frequency of droughts in Africa which occurs after every 3 to 5 years as indicated in Table 1 [39]. Notably, most of the indicated droughts occurred in the Horn of Africa (HOA) and Eastern Africa. The exposure to high frequency of severe droughts in East Africa was associated with the spatial location of the region along the coast of the Indian Ocean [14] [15]. In concurrence with these studies, the frequent droughts in East Africa were also linked to the rise in sea surface temperatures (SST) in the Indian Ocean [41]. The rise in both terrestrial temperatures and SST along the Indian Ocean was directly associated with climate change events, Indian Ocean Dipole and Inter-tropical Convergence Zone.

Projections of $5 \%$ to $8 \%$ increase in aridity and ASALs in Africa by 2100 were associated with climate change-driven droughts [39]. The projected increase in aridity in the continent will potentially limit the productivity of agricultural lands and destroy the biotic life forms. On the other hand, the study pointed out 
Table 1. Major African droughts from 1980 to 2008.

\begin{tabular}{|c|c|c|}
\hline Country & Years Affected & Nearest $(0.1 \mathrm{mn})$ \\
\hline \multirow{7}{*}{ Kenya } & 2008 & 1.4 \\
\hline & $2005-06$ & 3.5 \\
\hline & 2004 & 2.3 \\
\hline & 1999-02 & 23.0 \\
\hline & $1997-98$ & 1.6 \\
\hline & $1994-95$ & 1.2 \\
\hline & $1991-92$ & 2.7 \\
\hline \multirow{6}{*}{ Ethiopia } & 2008 & 6.4 \\
\hline & 2003-04 & 12.6 \\
\hline & 1997 & 1.0 \\
\hline & $1989-94$ & 6.5 \\
\hline & 1987 & 7.0 \\
\hline & $1983-84$ & 7.8 \\
\hline \multirow{4}{*}{ Sudan } & $2000-01$ & 2.0 \\
\hline & $1991-92$ & 8.6 \\
\hline & 1987 & 3.5 \\
\hline & $1983-85$ & 8.4 \\
\hline \multirow{3}{*}{ Eritrea } & 2008 & 1.7 \\
\hline & 1999-03 & 2.3 \\
\hline & 1993 & 1.6 \\
\hline \multirow{3}{*}{ Somalia } & 2008 & 3.3 \\
\hline & $2000-01$ & 1.2 \\
\hline & 1987 & 0.5 \\
\hline
\end{tabular}

Adopted from [39].

an increase in annual mean rainfall in West Africa (dry Sahel) where vegetative regeneration was noted [11]. However, a decline in rainfall in Mediterranean basin and negative evolution of the ecosystems were observed and were linked to climate change. Since crop production principally depends on availability of water, increasing rainfall trends in West Africa therefore potentially create and opportunity for increased crop production for rain-fed agriculture.

Climate change leads to high wind speeds due to pressure cells difference, causing coastal soil erosion, general soil degradation and decline in soil productivity [2] [17] [22]. Climate change leads to increased cases of dust storms and threats of respiratory diseases [4]. An increase of $1 \%$ to $8 \%$ in hurricane wind speeds was associated with $1 \%$ to $18 \%$ increase in hurricane rainfall [42]. The study also indicated that these events were attributed to a $1.0^{\circ} \mathrm{C}$ increase in sea warming. In addition to these observations, climate change influences the de- 
velopment of land and sea breezes, where winds determine the development and distribution of precipitation around coastal regions. Further, winds transport pollen and enable pollination thereby enabling floral continuity.

Sub-Saharan Africa (SSA) is a largely vulnerable region where the impacts of climate change are significant and spatio-temporally spread [43]. In addition, the study established projections of increased temperatures and variable rainfall patterns that will consequently lead to higher frequency of droughts and floods in the region. The impact of climate change is increasing vulnerability in SSA [11]. Further, the study revealed that agricultural production in SSA was majorly affected by the phenomenon exemplified by increasing drought and water stress. The study also posited that increasing aridity and desertification, degradation of farmlands and increasing wild fires were associated with climate change and reduced crop and vegetative cover. The increased frequency of droughts in SSA and the consequent water stress is a major challenge to ecosystem stability and survival of biotic systems.

Increased frequency of droughts in the HOA which is associated with climate change was recorded in Ethiopia and Tanzania in 2000, 2009 and 2011 [41]. Eastern Africa is one of the most climate change vulnerable regions in the continent due to the spatial location along the Indian Ocean coast [39] [44]. Further, the study established that as a rain-fed agriculture dependent region, rainfall variability and increased temperatures will potentially limit agro-productivity hence food insecurity. Tanzania and Kenya are significantly affected by climate change due to location, demographic structures and low climate change mitigation and adaptation capabilities [14] [15]. An increase in annual mean rainfall in East Africa, where regeneration of vegetation in degraded and drought affected ASALs was realized [11]. Notably, the effect of climate change is significantly experienced in East Africa where climate change events such as droughts and floods have become more frequent and near annual. These events have led to terrestrial resources degradation where soil erosion, land degradation and biotic resources degradation are recorded regularly.

Significant increase in temperature trends in Kenya since 1960s was identified [43]. The study also indicated that the positive warming trends were accompanied by spasmodic rainfall patterns and more frequent droughts and flood events. These climatic events are linked to climate change which has further led to increased cases of pests and diseases on terrestrial and aquatic ecosystems. The increase in pests and diseases leads to significant ecosystem destruction. Variability in seasonal rainfall in ASALs in Kenya significantly affects crop production [13]. Furthermore, occurrence of bi-annual rainfall seasons in Kenya was reported. It was established that climate change has led to more frequent droughts in Kenya with occurrence reducing from after every 5 to 3 years [12]. On the same note, significant impacts of more severe and extreme droughts in the lowland ASALs of Eastern Kenya that includes Kitui and Tharaka Nithi Counties was reported [45]. In addition, the study noted increase in rainfall during the 
short rainfall season (October to November) which is the main planting season in the ASAL region. The notable increase in climate change events such as droughts, heat and water stress and flood events in Kenya has caused massive damage on the ecosystems and led to crops and livestock loss. In addition, the resultant agricultural loss has increased the cases of food insecurity more particularly in ASALs in Kenya that practice rain-fed crop production.

\section{Conclusion}

The increase in global temperatures through green-house effect and global warming and the consequent climate change, has significant impact on the global and regional ecosystems and the environment. Climate change was found to lead to declining mountain snow cover, ice melts, and increasing sea levels, increasing aquatic salinity, increasing atmospheric and aquatic acidification thereby reducing aquatic biodiversity, causing land and ecosystem degradation leading to biotic environment destruction. Heat stress, drought stress and water stress were also accompanied by catastrophic atmospheric circulation causing flooding. These impacts affected the natural, agronomic, economic and human resources productivity. Climate change also affects human health leading to increased mortalities. Climate change therefore, limits productivity of the global terrestrial, aquatic, atmospheric, abiotic and biotic environments. The study identified gaps in quantification of the impact of anthropogenic-driven climate change on the environment and mitigation strategies.

\section{Conflicts of Interest}

The authors declare no conflicts of interest.

\section{References}

[1] Patil, A. and Lamnganbi, M. (2018) Impact of Climate Change on Soil Health: A Review. International Journal of Chemical Studies, 6, 2399-2404.

[2] Benateau S., Gaudard A., Stamm C. and Altermatt F. (2019) Climate Change and Freshwater Ecosystems: Impacts on Water Quality and Ecological Status. Hydro-CH 2018 Project, Federal Office for the Environment (FOEN), Bern, Switzerland. 110 p. https://doi.org/10.5167/uzh-169641

[3] Food and Agriculture Organization of the United Nations (FAO) (2008) Climate Change, Energy and Food. High-Level Conference on Food Security: The Challenges of Climate Change and Bioenergy Climate-Related Trans-Boundary Pests and Diseases. Technical Background Document from the Expert Consultation, 25-27 February 2008, Food and Agriculture Organization of the United Nations, Rome. 3-5 June 2008 HLC/08/BAK/4.

[4] Physicians for Social Responsibility (PSR) (2012) Climate Change and Health: Climate Change Contaminates Your Water. https://www.psr.org

[5] Jean-Yves, H. and Verdier, L. (2013) What Is the Impact of Globalisation on the Environment? In Economic Globalisation: Origins and consequences, OECD Publishing, Paris.

[6] Lovins, L.H. and Cohen, B. (2011) Climate Capitalism: Capitalism in the Age of Cli- 
mate Change. Hill and Wang, New York. https://ncse.ngo/files/pub/evolution/excerpt--capitalism2--fb.pdf

[7] World Health Organization (2019) WHO Global Strategy on Health, Environment and Climate Change: The Transformation Needed to Improve Lives and Wellbeing Sustainably through Healthy Environments. World Health Organization, Geneva.

[8] Mont, G. and Fraga, F. (2018) The Future of Work in Natural Changing Environment: Climate Change, Degradation and Sustainability. International Labour Organization [ILO]. International Labour Office, Geneva.

[9] Reid, H. and Swiderska, K. (2008) Biodiversity, Climate Change and Poverty: Exploring the Links. An IIED Briefing. International Institute for Environment and Development, London. http://www.iied.org

[10] Verweij, W., Van der Wiele, J., Van Moorselaar, I. and Van der Grinten, E. (2010) Impact of Climate Change on Water Quality in the Netherlands. RIVM Report 607800007/2010. National Institute for Public Health and the Environment, Bilthoven.

[11] United Nations Framework Convention on Climate Change (UNFCCC) (2007) Climate Change: Impacts, Vulnerabilities and Adaptation in Developing Countries. United Nations Framework Convention on Climate Change, New York, Rio de Janeiro. http://www.unfccc.int

[12] Karanja, A. (2013) Analysis of Rainfall Variability on Irish Potato Production in Ol-Joro Orok Division, Nyandarua County, Kenya. A Thesis Submitted in Partial Fulfillment for the Award of the Degree of Master of Arts in The School of Humanities and Social Sciences of Kenyatta University, Nairobi.

[13] Ondiko, H.J., Ochieng', R. and Karanja, M.A. (2018) Rainfall Variability Coping Strategies for Improved Food Security: A Case Study of Baringo South, Baringo County, Kenya. The International Journal of Humanities \& Social Studies, 6, 198206.

[14] Hallegatte, S., Bangalore, M., Bonzanigo, L., Fay, M., Tamaro, K., Narloch, U., Rosenberg, J. and Schilb, A.V. (2014) Climate Change and Poverty. Climate Change Group, Office of the Chief Economist, Washington DC.

[15] Hallegatte, S., Kane, T. and Bangalore, M. (2015) Climate Change and Poverty: Conference Summary. World Bank, Washington DC.

[16] Flecher, R. (2012) Capitalism on Chaos: Climate Change and Disaster Capitalism. Ephemera, 12, 97-112. HTTPS://www.ephemeraweb.org

[17] Barbier, E.B. and Hochard, J.P. (2018) The Impacts of Climate Change on the Poor in Disadvantaged Regions Review of Environmental Economics and Policy. Review of Environmental Economics and Policy, 12, 26-47. https://doi.org/10.1093/reep/rex023

[18] Myers, S.S., Gaffikin, L., Golden, C.D., Ostfeld, R.S., Redforde, K., Ricketts, T.H., Turner, W.R. and Osofskyha, S.A. (2012) Human Health Impacts of Ecosystem Alteration. Proceedings of the National Academy of Sciences of the United States of America, 110, 18753-18760. https://doi.org/10.1073/pnas.1218656110 https://www.pnas.org/cgi/doi/10.1073/pnas.1218656110

[19] Almeida, P. (2019) Climate Justice and Sustained Transformational Mobilisation. Globolizations, 16, 973-979. https://doi.org/10.1080/14747731.2019.1651518

[20] United States Agency for Environmental Protection (EPA) (2017) Green House Gas Emissions: Overview of Green House Gases. United States Agency for Environmental Protection, Washington DC. https://www.epa.gov 
[21] Brouder, S.M. and Volenec, J.J. (2008) Impact of Climate Change on Crop Nutrient and Water Use Efficiencies. Physiologia Plantarum, 133, 705-724. https://doi.org/10.1111/j.1399-3054.2008.01136.x

[22] Fang, J., Yu, G., Liu, L., Hu, S. and Chapin, F.S. (2018) Climate Change, Human Impacts and Carbon Sequestration in China. Proceedings of the National Academy of Sciences of the United States of America, 115, 4015-4020.

https://doi.org/10.1073/pnas.1700304115 https://www.pnas.org/cgi/doi/10.1073/pnas.1700304115

[23] Teh, S.T. and Koh, H.L. (2016) Climate Change and Soil Salinization: Impact on Agriculture, Water and Food Security. International Journal of Agriculture, Forestry and Plantation, 2, 1-9.

[24] Al-Najar, H. and Ashour, E.K. (2013) The Impact of Climate Change and Soil Salinity in Irrigation Water Demand on the Gaza Strip. Agricultural planning and climate change. Journal of Water and Climate Change, 4, 118-130.

https://doi.org/10.2166/wcc.2013.142 https://iwaponline.com/jwcc/article-Pdf/4/2/118/374867/118.pdf

[25] Balkovič, J., Skalský, R., Folberth, C., Khabarov, N., Schmid, E., Madaras, M., Obersteiner, $\mathrm{M}$, and van der Velde, M. (2018) Impacts and Uncertainties of $+2^{\circ} \mathrm{C}$ of Climate Change and Soil Degradation on European Crop Calorie Supply. Earth's Future, 6, 373-395. https://doi.org/10.1002/2017EF000629

[26] McGuigan, C., Reynolds, R. and Wiedner, D. (2002) Poverty and Climate Change: Assessing Impacts in Developing Countries and the Initiatives of the International Community. London School of Economics, London.

[27] Intergovernmental Panel on Climate Change (IPCC) (2013) Summary for Policymakers in Climate Change 2013: The Physical Science Basis. Contribution of Working Group I to the Fifth Assessment Report of the Intergovernmental Panel on Climate Change (Stocker, T.F., Qin, D., Plattner, G.-K., Tignor, M., Allen, S.K., Boschung, J., Nauels, A., Xia, Y., Bex, V. and Midgley, P.M. (Eds.)) Cambridge University Press, Cambridge and New York.

[28] Intergovernmental Panel on Climate Change (IPCC) (2018) Global Warming of $1.5^{\circ} \mathrm{C}$. Intergovernmental Panel on Climate Change, Geneva. https://www.ipcc.ch

[29] Dasgupta, S., Hossain, M., Huq, M. and Wheeler, D. (2015) Climate Change and Soil Salinity: The Case of Coastal Bangladesh. Ambio, 44, 815-826.

https://doi.org/10.1007/s13280-015-0681-5

[30] Mountain Research and Development (2019) African Mountains in a Changing Climate: Trends, Impacts, and Adaptation Solutions, 39, 1-8. https://doi.org/10.1659/MRD-JOURNAL-D-19-00062.1

[31] Haddeland, I., Heinke, J., Biemans, H., Eisner, S., Flörke, M., Hanasaki, N., Konzmann, M., Ludwig, F., Masaki, Y., Scheweb, J., Stackeg,T., Tesslerh, Z.D., Wadai, Y. and Wisseri, D. (2014) Global Water Resources Affected by Human Interventions and Climate Change. Proceedings of the National Academy of Sciences of the United States of America, 111, 3251-3256. https://doi.org/10.1073/pnas.1222475110 https://www.pnas.org/cgi/doi/10.1073/pnas.1222475110

[32] Whitehead, P.G., Wilby, R.L., Battarbee, R.W., Kernan, M. and Wade, A.J. (2009) A Review of the Potential Impacts of Climate Change on Surface Water Quality. Hydrological Sciences Journal, 54, 101-123. https://doi.org/10.1623/hysj.54.1.101

[33] Adams, R.M. and Peck, D.E. (2008) Effects of Climate Change on Water Resources. Choices, 23, 12-14.

[34] Pugnaire, F.I., Morillo, J.A., Peñuelas, J., Reich, P.B., Bardgett, R.D., Gaxiola, A., 
Wardle, D. and Van der Putten, W.H. (2019) Climate Change Effects on Plant-Soil Feedbacks and Consequences for Biodiversity and Functioning of Terrestrial Ecosystems. Science Advances, 5, Article No. eaaz1834.

https://doi.org/10.1126/sciadv.aaz1834

http://advances.sciencemag.org

[35] Gozzo, L.F., Palma, D., Custodio, S. and Machado, P. (2019) Climatology and Trend of Severe Drought Events in the State of Sao Paulo, Brazil, during the 20th Century. Atmosphere, 10, Article No. 190. https://doi.org/10.3390/atmos10040190

[36] Queiroz, M.S., Oliveira, C.E.S., Steiner, F., Zuffo, A.M., Zoz, T., Vendruscolo, E.P., Silva1, M.V., Mello, B.F.F.R., Cabral1, R.C. and Menis, F.T. (2018) Drought Stresses on Seed Germination and Early Growth of Maize and Sorghum. Journal of Agricultural Science, 11, 310-318. https://doi.org/10.5539/jas.v11n2p310

[37] Mag, K., Ouma, J.P.A. and Ojwang, P.P.O. (2017) Effect of Sowing date on Grain Quality of Sorghum (Sorghum bicolor L Moench) in the Nile Corridor Agroecological Zone of South Sudan. African Journal of Food, Agriculture, Nutrition and Development, 17, 12657-12677. https://doi.org/10.18697/ajfand.80.16520

[38] Souza, A.P., Cocuron, J.C., Garcia, A.C., Alonso, A.P. and Marcos S.B. (2015) Changes in Whole-Plant Metabolism During the Grain-Filling Stage in Sorghum Grown under Elevated $\mathrm{CO}_{2}$ and Drought. Plant Physiology, 169, 1755-1765.

https://www.plantphysiol.org

[39] Gemeda, D.O. and Sima, A.D. (2015) The Impacts of Climate Change on African Continent and the Way Forward. Journal of Ecology and the Natural Environment, 7, 256-262. https://doi.org/10.5897/JENE2015.0533 http://www.academicjournals.org/JENE

[40] Naser, M.M. (2012) Climate Change, Environmental Degradation, and Migration: A Complex Nexus. William \& Mary Environmental Law and Policy Review, 36. https://scholarship.law.wm.edu/wmelpr/vol36/iss3/4

[41] Funk, C., Hoell, A., Shukla, S., Bladé, I., Liebmann, B., Roberts, J.B., Robertson, F.R. and Husak, G. (2014) Predicting East African Spring Droughts Using Pacific and Indian Ocean Sea Surface Temperature Indices. Hydrology and Earth System Sciences, 18, 4965-4978. https://doi.org/10.5194/hess-18-4965-2014

[42] Sealy, H. (2018) Caribbean Perspectives of the Impact of Climate Change on Environmental Determinants of Health. Windward Islands Research and Education Foundation (WINDREF) the III Global Conference on Health and Climate Change, Grenada, 16-17 October 2018, 1-26.

[43] Chepkoech, W., Mungai, N.W., Stöber, S., Bett, H.K. and Lotze-Campen, H. (2018) Farmers' Perspectives on Impact of climate change on African Indigenous Vegetable Production in Kenya. International Journal of Climate Change Strategies and Management, 10, 551-579. https://doi.org/10.1108/IJCCSM-07-2017-0160

[44] Degefu, M.A., Assen, M. and McGahey, D. (2018) Climate Variability and Impact in ASSAR's East African Region. CARIAA-ASSAR Working Paper. International Development Research Centre, Ottawa, Canada and UK Aid, London, United Kingdom.

http://www.assar.uct.ac.za/sites/default/files/image tool/images/138/Publications/A SSAR\%20working\%20paper\%20on\%20climate\%20variability\%20in\%20East\%20Afri ca\%20-\%20March\%202018.pdf

[45] Recha (2018) Droughts in Eastern Kenya: What This Means for Drought Management. PolicyBrief. https://www.slu.se 